\title{
Thick Juice-Based Production of Amino Acids and Putrescine by Corynebacterium glutamicum
}

Tobias M Meiswinkel, Steffen N Lindner and Volker F Wendisch*

Chair of Genetics of Prokaryotes, Faculty of Biology and CeBiTec, Bielefeld University, Germany

\begin{abstract}
Thick juice (also regarded as syrup) is an intermediate product of sugar processing. It is cheaper than processed sugar and is mainly composed of sucrose. Sucrose is a preferred carbon source of Corynebacterium glutamicum, a workhorse of biotechnology used for million-ton-scale amino acid production. Here, it is shown for $C$. glutamicum that sugar beet thick juice led to higher growth rates and faster carbon source consumption than pure sucrose. Comparative DNA microarray analysis revealed differential expression of genes for butyrate and citrate catabolism and of NAD and biotin biosynthesis suggesting provision of these compounds by the thick juice. Thick juice was also shown to be superior to sucrose in production of the amino acids L-lysine, L-glutamate and L-arginine as well as of the diamine putrescine since higher volumetric productivities than with pure sucrose could be achieved. Taken together, sugar beet thick juice was shown to be a carbon source for growth and amino acid and diamine production of C. glutamicum superior to pure sucrose.
\end{abstract}

Keywords: Thick juice; L-lysine; L-glutamate; L-arginine; Putrescine; Corynebacterium glutamicum

\section{Introduction}

With resources of fossil oil becoming limiting, biotechnological production is getting more and more attractive $[1,2]$. Regarding the production of bulk chemicals the use of alternative carbon source for fermentation has become highly interesting to allow competing prices. One prospect is the use of thick juice, an intermediate product from sugar industry.

While production of table sugar involves many steps starting with e.g. sugar beet or sugar cane and ending in white crystalline sugar. First sugar beet is washed thoroughly and cut into chips. Out of these chips a crude juice is extracted by hot water treatment. This crude juice contains about $150 \mathrm{~g} \mathrm{l}^{-1}$ sugar as well as several contaminants. These contaminants are removed by filtration resulting in light yellow colored thin juice. Using low temperature and high vacuum conditions water is reduced and thick juice is generated with a sugar content of 650-700 $\mathrm{g} \mathrm{l}^{-1}$. In order to get white crystalline sugar further concentration and cleaning steps like crystallization and centrifugation are required [3]. By using thick juice instead of fully processed sugar these steps are saved and thereby also the associated costs.

Until now thick juice has received only little attention as a carbon source in biotechnology. Conservation of thick juice and its microbial degradation have been studied [4-7]. Other sugar beet based substrates like beet sugar molasses [8] have been used to produce fructose and ethanol. In food biotechnology, sugar beet thick juice in combination with beet sugar molasses have been used for the production of fructooligosaccharides [9].

The Gram-positive soil bacterium Corynebacterium glutamicum is generally recognized as safe (GRAS) and used for the million-tonscale production of amino acids. Besides being used for L-glutamate and L-lysine production, C. glutamicum has been engineered for the production of diamines like putrescine (1,4-diaminobutane) [10,11] and cadaverine (1,5-diaminopentane) [12-14], ketoacids such as pyruvate [15] and 2-ketoisovalerate [16], diacids such as succinate [17-20], the alcohols ethanol [21] and iso-butanol [22], and further amino acids, e.g. L-arginine, L-ornithine [23] and L-proline [24] or carotenoids [25] as well as gamma-amino butyric acid [26].
Amino acid production by C. glutamicum is typically based on glucose from starch hydrolysates and fructose and sucrose from molasses. These sugars are imported and phosphorylated by the phospho-transferase system (PTS) [27]. While fructose and sucrose are transported via the PTS only, PTS-independent glucose uptake has been reported and characterized [28,29]. For access to further carbon sources C. glutamicum has been metabolically engineered: e.g. for access to xylose and arabinose, which can be found in hydrolysates of agricultural wastes [23,30-33], starch [34,35], cellobiose [36], as well as lactose and galactose, which are present in whey $[37,38]$ or the chitin monomer glucosamine [39]. To the best of our knowledge, the use of thick juices or syrups for biotechnological processes with $C$. glutamicum has not yet been reported. Therefore, the genetic response of C. glutamicum to thick juice has been analyzed by transcriptomics and the performance of thick juice-based production by C. glutamicum has been compared production with sucrose.

\section{Methods}

\section{Strains and culturing conditions}

All C. glutamicum strains used are listed in Table 1. For growth and production experiments CgXII medium [40] in $500 \mathrm{ml}$ baffled shaking flasks was inoculated from LB overnight cultures and cultivated at $30^{\circ} \mathrm{C}$ and $120 \mathrm{rpm}$. Production of L-glutamate was triggered by $500 \mu \mathrm{g} \mathrm{ml}{ }^{-1}$ ethambutol[41]. Media for C. glutamicum ORN1 were supplemented with $500 \mu \mathrm{M}$ L-arginine. Growth was followed by the determination of $\mathrm{OD}_{600}$, which was measured using a UV-1650 PC photometer (Shimadzu, Duisburg, Germany). When appropriate 100

*Corresponding author: Volker F Wendisch, Chair of Genetics of Prokaryotes Faculty of Biology and CeBiTec, Bielefeld University, Universitätsstr 25, D-33615 Bielefeld, Germany, Tel: 00495211065611; E-mail: volker.wendisch@uni-bielefeld.de

Received August 19, 2014; Accepted October 06, 2014; Published November 15,2014

Citation: Meiswinkel TM, Lindner SN, Wendisch VF (2014) Thick Juice-Based Production of Amino Acids and Putrescine by Corynebacterium glutamicum. J Biotechnol Biomater 4: 167. doi:10.4172/2155-952X.1000167

Copyright: (C) 2014 Meiswinkel TM, et al. This is an open-access article distributed under the terms of the Creative Commons Attribution License, which permits unrestricted use, distribution, and reproduction in any medium, provided the original author and source are credited. 
Citation: Meiswinkel TM, Lindner SN, Wendisch VF (2014) Thick Juice-Based Production of Amino Acids and Putrescine by Corynebacterium glutamicum. J Biotechnol Biomater 4: 167. doi:10.4172/2155-952X.1000167

Page 2 of 6

\begin{tabular}{|c|c|c|}
\hline Strain & Relevant characteristics & Reference \\
\hline WT & Wild type; ATCC13032 & [43] \\
\hline DM1729 & L-lysine overproducing strain, pyc ${ }^{\mathrm{P} 458 \mathrm{~S}}$, hom $^{\mathrm{V} 59 \mathrm{~A}}$, lys $^{\mathrm{T} 3111}$ & [44] \\
\hline PUT21 & Putrescine producing strain, ORN1 carrying pVWEx1-speC $C^{521}$-argF & [11] \\
\hline ARG1 & 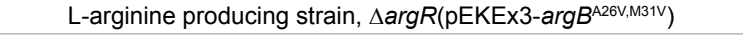 & [23] \\
\hline
\end{tabular}

Table 1: C. glutamicum strains used.

\begin{tabular}{|c|c|c|c|c|}
\hline \multicolumn{2}{|c|}{ Gene } & \multirow[b]{2}{*}{ operon } & \multirow[b]{2}{*}{ function } & \multirow{2}{*}{$\begin{array}{l}\text { relative mRNA levels } \\
\text { thick juice/sucrose }\end{array}$} \\
\hline designation & name & & & \\
\hline cg0095 & bio $B$ & OP_cg0095 & biotinsynthase & 2.6 \\
\hline $\operatorname{cg} 0096$ & - & OP_cg0095 & hypothetical protein & 2.5 \\
\hline $\operatorname{cg} 0566$ & $g a b T$ & OP_cg0566 & 4-aminobutyrate aminotransferase & 5.3 \\
\hline $\operatorname{cg} 0567$ & $g a b D$ & OP_cg0566 & succinate-semialdehydedehydrogenase & 8.3 \\
\hline $\operatorname{cg} 0568$ & $g a b P$ & OP_cg0566 & permease for amino acids & 2.4 \\
\hline cg0793 & - & - & secreted protein & 2.2 \\
\hline $\operatorname{cg} 1745$ & - & - & putative signal recognition particle GTPase & 2.6 \\
\hline $\operatorname{cg} 3105$ & - & OP_cg3106 & hypothetical protein & 2.2 \\
\hline $\operatorname{cg} 3125$ & $\operatorname{tct} A$ & OP_cg3127 & citrate uptake system, subunit $A$ & 3.0 \\
\hline $\operatorname{cg} 3126$ & $t c t B$ & OP_cg3127 & citrate uptake system, subunit B & 5.1 \\
\hline $\operatorname{cg} 3127$ & tctC & OP_cg3127 & citrate uptake system, subunit C & 7.6 \\
\hline cg3226 & - & - & permease of the major facilitator superfamily & 7.1 \\
\hline cg0156 & cysR & - & Bacterial regulatory proteins, Crp family & 0.4 \\
\hline cg0160 & - & OP_cg0160 & hypothetical protein & 0.2 \\
\hline cg0654 & $r p s D$ & OP_cg0651 & ribosomal protein S4 & 0.5 \\
\hline cg0759 & prpD2 & OP_cg0759 & methylaconitase & 0.4 \\
\hline $\operatorname{cg} 0762$ & prpC2 & OP_cg0759 & methylcitratesynthase & 0.5 \\
\hline $\operatorname{cg} 0771$ & - & OP_cg0771 & DtxR/iron regulated lipoprotein precursor & 0.5 \\
\hline $\operatorname{cg} 0924$ & - & - & ABC-type iron siderophore transport subunit & 0.4 \\
\hline cg0926 & - & OP_cg0926 & ABC-type iron siderophore transport subunit & 0.4 \\
\hline cg1214 & nadS & OP_cg1218 & cysteine sulfinate desulfinase & 0.4 \\
\hline cg1215 & nadC & OP_cg1218 & nicotinate-nucleotidepyrophosphorylase & 0.4 \\
\hline cg1216 & nadA & OP_cg1218 & quinolinatesynthetase & 0.3 \\
\hline $\operatorname{cg} 1287$ & - & - & hypothetical protein & 0.5 \\
\hline cg1765 & sufR & OP_cg1765 & predicted transcriptional regulator & 0.4 \\
\hline cg1855 & hisS & OP_cg1856 & histidyl-tRNA synthetase & 0.4 \\
\hline cg2055 & - & - & putative membrane protein & 0.4 \\
\hline $\operatorname{cg} 3119$ & fpr2 & - & probable sulfitereductase (flavoprotein) & 0.4 \\
\hline $\operatorname{cg} 3185$ & - & - & hypothetical protein & 0.5 \\
\hline
\end{tabular}

Table 2: DNA Microarray.

$\mu \mathrm{g} \mathrm{ml} l^{-1}$ spectinomycin, $25 \mu \mathrm{g} \mathrm{ml}^{-1}$ kanamycin, and $1 \mathrm{mM}$ isopropyl- $\beta$ D-thiogalactopyranosid (IPTG) were added to the medium to select and induce the plasmids listed in Table 1 . Biomasses in g cell dry weight per liter $\left(\mathrm{g} \mathrm{CDW} \mathrm{l}^{-1}\right)$ were calculated from $\mathrm{OD}_{600}$ as described previously by using a factor of $0.25 \mathrm{~g} \mathrm{CDW}^{-1}$ per $\mathrm{OD}_{600}[42]$.

\section{Thick juice}

Thick juice was obtained from Pfeifer and Langen Company, Jülich, Germany. Sucrose concentration in thick juice was $642 \mathrm{~g} \mathrm{l}^{-1}$.

\section{Determination of amino acid, diamine, and sucrose concentrations}

Amino acids, putrescine and sucrose concentrations were quantified by HPLC as described previously $[10,44,45]$.

\section{Global gene expression analysis}

Preparation of total RNA, cDNA synthesis, DNA microarray hybridization, and gene expression analysis were performed as described before [46-48]. C. glutamicum WT strain ATCC 13032 was used for this experiment. Growth conditions were CgXII minimal medium with $100 \mathrm{mM}$ of either pure sucrose or the equivalent thick juice as carbon source.

\section{Results}

\section{Utilization of thick juice by C. glutamicum}

C. glutamicum WT which is able to utilize sucrose as sole carbon source via $\mathrm{PTS}_{\mathrm{S}}$ was used for growth experiments with thick juice. The sucrose concentration in the thick juice used was determined by HPLC as $642 \mathrm{~g} \mathrm{l}^{-1}$. Growth experiments were carried out using CgXII minimal medium containing a final sucrose concentration of $34 \mathrm{~g} \mathrm{l}^{-1}$ either from thick juice or from pure sucrose. C. glutamicum WT was inoculated to a starting biomass of $0.25 \mathrm{~g} \mathrm{CDW} \mathrm{l}^{-1}$ and growth was followed. As depicted in Figure 1A, growth with thick juice was slightly faster $(0.56 \pm$ $\left.0.00 \mathrm{~h}^{-1}\right)$ than with pure sucrose $\left(0.49 \pm 0.02 \mathrm{~h}^{-1}\right)$ and the carbon source was depleted faster (after $9.5 \mathrm{~h}$ and $10.8 \mathrm{~h}$, respectively). However, the final biomass concentrations were comparable $\left(13.6 \pm 0.5 \mathrm{~g} \mathrm{CDW} \mathrm{l}^{-1}\right.$ with thick juice and $13.1 \pm 1.3 \mathrm{~g} \mathrm{CDW}^{-1}$ with pure sucrose). 

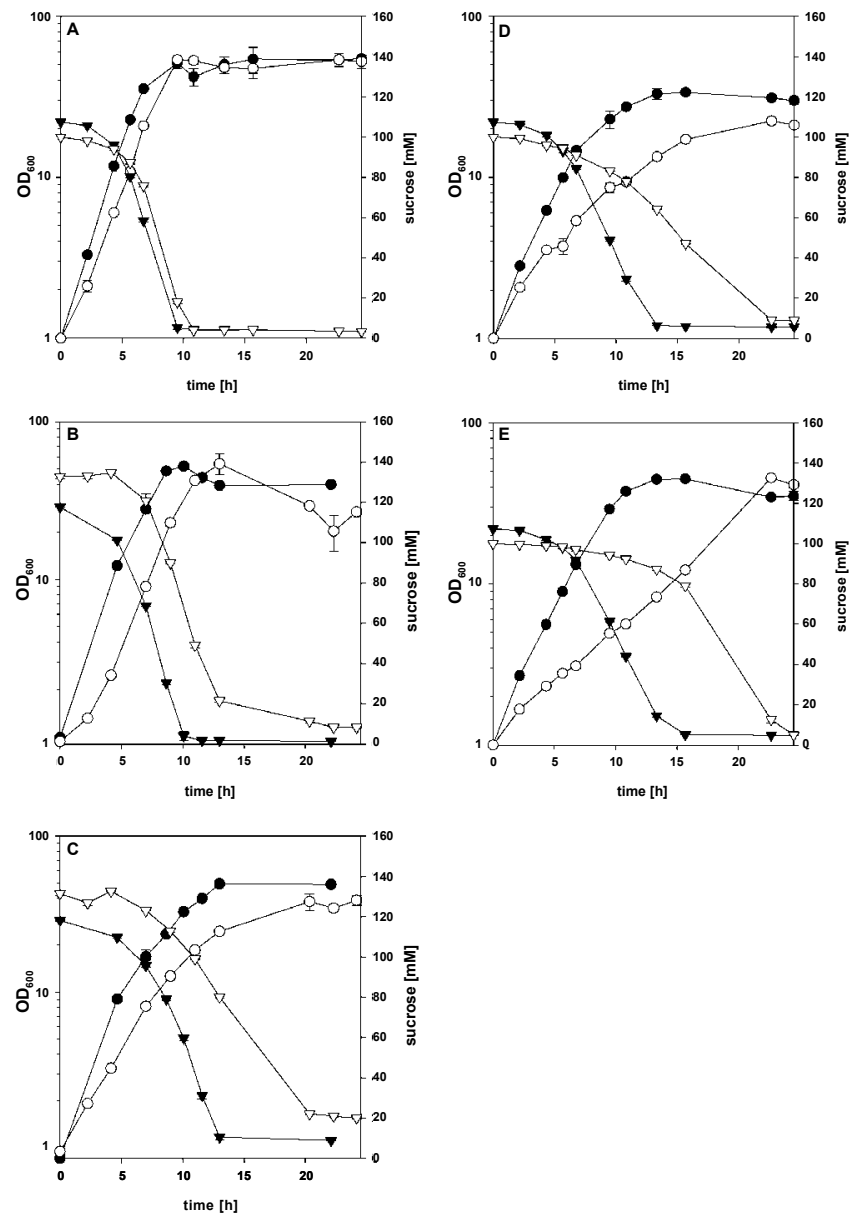

Figure 1: Growth (circles) and sucrose consumption (triangles) of various $C$ glutamicum strains.

With thick juice (closed symbols) or pure sucrose (open symbols), $C$ glutamicum WT (A), the L-lysine producing DM1729 (B), L-glutamate producing WT (C), putrescine producing PUT21 (D) and L-arginine producing ARG1 (E) were cultivated on $\mathrm{Cg}$ XII minimal medium. When appropriate IPTG antibiotics or ethambutol was added. Data are means and standard deviations of three $(A$ $D, E)$ or two $(B, C)$ replicates.

\section{DNA Microarray analysis of thick juice-specific gene expression changes}

In order to characterize growth of C. glutamicum with thick juice on the gene expression level, C. glutamicum WT was grown in Cg XII minimal medium with pure sucrose or thick juice as carbon source. At a biomass of $1 \mathrm{~g} \mathrm{CDW} \mathrm{l}^{-1}$ cells were harvested, total RNA isolated and cDNA synthesized using Cye Dyes to label the different pools of cDNA. After DNA microarray hybridization and scanning, different expression levels were analyzed using Genepix software.

Table 2 lists statistically significant expression differences for 29 genes in the transcriptome comparison of sucrose- and thick juicegrown C. glutamicum WT cells. Of the 17 genes that showed lower mRNA levels on thick juice as compared to pure sucrose, five genes code for proteins which are organized in two operon structures ( $p r p D 2$ and prpC2 of OP_cg0759; nadS, nadC and nadA of OP_cg1218). Furthermore, two genes show lower mRNA levels which code for proteins involved in iron uptake (cg0924, $\operatorname{cg} 0926)$.
Increased gene expression during growth on thick juice was observed for twelve genes. Among these were eight genes of three operons, namely bioB and cg0096 (OP_cg0095; involved in biotin synthesis), gabTDP (OP_cg0566; involved in butyrate utilization) as well as $t c t A B C$ (OP_cg3127; for citrate uptake).

Taken together, growth of C. glutamicum on thick juice differed from growth on pure sucrose by increased expression of genes for butyrate and citrate utilization and for biotin synthesis and by decreased expression of genes for iron uptake, NAD synthesis and propionate catabolism (Table 2).

Comparative global gene expression analysis of C. glutamicum WT grown in minimal medium with thick juice or pure sucrose as carbon source.

\section{Amino acid and putrescine production on sucrose and thick juice}

To characterize production of C. glutamicum with thick juice, various engineered C. glutamicum strains were used. Besides production of the amino acids L-lysine, L-glutamate and L-arginine, production of the diamine putrescine, which is synthesized from an intermediate of arginine biosynthesis, was done comparing pure sucrose and thick juice. All strains were inoculated to a final biomass concentration of $0.25 \mathrm{~g} \mathrm{CDW}^{-1}$ into Cg XII minimal medium containing $34 \mathrm{~g} \mathrm{l}^{-1}$ sucrose either from thick juice or from pure sucrose. Figure 1 shows growth and carbon source depletion during the respective production experiments. The maximal amino acids or diamine concentrations are summarized in Table 3. Specific productivities are given in Figure 2.

Strains and the respective growth and carbon source consumption charts are given in Figure 1. Product concentrations are given as

\begin{tabular}{|l|c|c|c|c|}
\hline & \multicolumn{4}{|c|}{ product concentration [mM] } \\
\hline substrate & L-glutamate & L-lysine & L-arginine & putrescine \\
\hline thick juice & $56.5 \pm 1.0$ & $33.0 \pm 0.2$ & $43.9 \pm 1.3$ & $46.6 \pm 1.3$ \\
\hline sucrose & $45.3 \pm 2.3$ & $14.4 \pm 1.4$ & $50.3 \pm 1.4$ & $49.4 \pm 3.6$ \\
\hline
\end{tabular}

Table 3: Maximal titers of produced amino acids and putrescine with thick juice or sucrose.

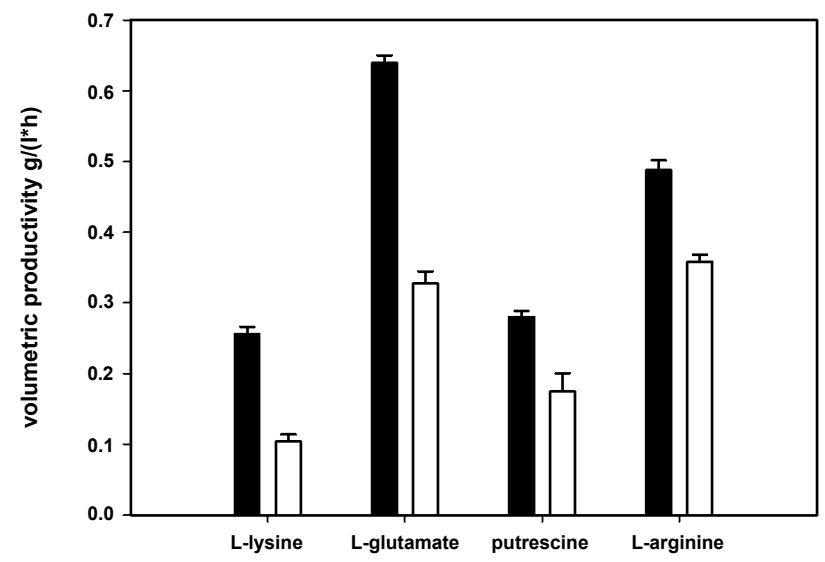

Figure 2: Volumetric productivities for L-lysine, L-glutamate, putrescine and L-arginine.

Production in $\mathrm{Cg}$ XII medium containing thick juice (black bars) or sucrose (white bars). Production conditions were as described in Methods and as in Figure 1. Data are means and standard deviations of three (putrescine, L-arginine) or two (L-lysine, L-glutamate) replicates. 
means and standard deviations of three (putrescine, L-arginine) or two (L-lysine, l-glutamate) replicates are given after sucrose was depleted.

\section{L-lysine production}

L-lysine production experiments were carried out with $C$. glutamicum DM1729 [44]. Samples for the determination of L-lysine concentrations were taken when sucrose was depleted. L-lysine accumulated to a concentration of $14.4 \pm 1.4 \mathrm{mM}$ with pure sucrose. When thick juice was used the final L-lysine concentration doubled to $33.0 \pm 0.2 \mathrm{mM}$ (Figure 1B). Comparable growth rates were observed for both conditions $\left(0.46 \pm 0.01 \mathrm{~h}^{-1}\right.$ with thick juice and $0.46 \pm 0.01 \mathrm{~h}^{-1}$ with pure sucrose). Sucrose from thick juice was depleted after 10.1 $\mathrm{h}$ and after $20.3 \mathrm{~h}$ in the experiment with pure sucrose. The resulting volumetric productivity was almost three times higher with thick juice $\left(0.26 \pm 0.01 \mathrm{~g} \mathrm{l}^{-1} \mathrm{~h}^{-1}\right)$ than with pure sucrose $\left(0.10 \pm 0.01 \mathrm{~g} \mathrm{l}^{-1} \mathrm{~h}^{-1}\right.$; Figure 2).

\section{L-glutamate production}

L-glutamate production experiments were carried out with $C$. glutamicum WT [49]. Production of L-glutamate by C. glutamicum WT needs to be triggered e.g. by addition of ethambutol [50] which was added during inoculation to a concentration of $500 \mu \mathrm{g} \mathrm{ml}^{-1}$. When sucrose was depleted, $45.3 \pm 2.3 \mathrm{mM}$ L-glutamate had accumulated with pure sucrose while around $25 \%$ more L-glutamate $(56.5 \pm 1.0$ $\mathrm{mM}$ ) accumulated with thick juice (Figure 1C). The use of thick juice resulted in an increased growth rate $\left(0.44 \pm 0.01 \mathrm{~h}^{-1}\right.$ as compared to 0.31 $\pm 0.01 \mathrm{~h}^{-1}$ with pure sucrose) and faster depletion of the carbon source (after $13 \mathrm{~h}$ with thick juice as compared to $20.3 \mathrm{~h}$ with pure sucrose). An about twofold higher volumetric productivity with thick juice $(0.64$ \pm 0.01 as compared to $0.33 \pm 0.02 \mathrm{~g} \mathrm{l}^{-1} \mathrm{~h}^{-1}$ with pure sucrose) entailed (Figure 2).

\section{L-arginine production}

C. glutamicum strain ARG1 [23] was used to demonstrate the use of thick juice for the production of L-arginine (Figure 1D). Growth with pure sucrose was twofold slower $\left(0.18 \pm 0.00 \mathrm{~h}^{-1}\right)$ than with thick juice $\left(0.35 \pm 0.00 \mathrm{~h}^{-1}\right)$. With pure sucrose $50.3 \pm 1.4 \mathrm{mM} \mathrm{L}$-arginine accumulated after sucrose depletion $(24.5 \mathrm{~h})$, which corresponds to a volumetric productivity of $0.36 \pm 0.01 \mathrm{~g} \mathrm{l}^{-1} \mathrm{~h}^{-1}$. With thick juice $43.9 \pm$ $1.3 \mathrm{mM}$ L-arginine accumulated, but sucrose was depleted already after $15.6 \mathrm{~h}$. The corresponding volumetric productivity on thick juice was increased by about one third to $0.49 \pm 0.01 \mathrm{~g} \mathrm{l}^{-1} \mathrm{~h}^{-1}$ (Figure 2).

\section{Putrescine production}

Putrescine production by C. glutamicum $[10,11]$ is based on over expression of the $E$. coli ornithine decarboxylase gene speC in the ornithine production strain ORN1 [23] via pVWEx1-speC-5'21$\arg F$, which also renders the respective strain PUT21 prototrophic for L-arginine due to leaky expression of $\arg F$ from the addiction plasmid [11]. When $34 \mathrm{~g} \mathrm{l}^{-1}$ pure sucrose were provided $49.4 \pm 3.6 \mathrm{mM}$ of putrescine were produced, which corresponds to a volumetric productivity of $0.17 \pm 0.03 \mathrm{~g} \mathrm{l}^{-1} \mathrm{~h}^{-1}$ since sucrose was depleted after 22.6 $\mathrm{h}$. When thick juice was used put rescine accumulated to comparable concentrations $(46.6 \pm 1.3 \mathrm{mM})$, but productivity increased significantly to $0.28 \pm 0.01 \mathrm{~g} \mathrm{l}^{-1} \mathrm{~h}^{-1}$ as sucrose was depleted already after $13.3 \mathrm{~h}$ and growth with thick juice was clearly faster $(0.36 \pm 0.00$ as compared to $0.19 \pm 0.01 \mathrm{~h}^{-1}$ with pure sucrose).

\section{Discussion}

Sugar beet thick juice-based production of amino acids L-glutamate, L-lysine and L-arginine and of the diamine putrescine by C. glutamicum is described here for the first time. While most crude substrates like technical grade glycerol [51] or hemi cellulosic hydrolysates [30,33] inhibit growth, thick juice was shown here to be beneficial for growth, carbon source utilization and amino acid and diamine production with C. glutamicum. Thick juice is an intermediate of the sugar production process with already high sucrose concentration, but there are still some sugar beet ingredients present, which can have advantageous effects.

Regarding the results obtained from global gene expression analysis higher expression levels for $b i o B$ and adjacent $\operatorname{cg} 0096$ were detected under thick juice conditions. C. glutamicum is biotin auxotroph due to an incomplete biotin synthesis pathway and therefore is dependent on biotin import via BioYMN [52]. Subsequently, biotin protein ligase BirA [53] catalyzes covalent attachment of biotin to the two biotindependent enzymes of C. glutamicum, acetyl-CoA carboxylase [54] and pyruvate carboxylase [55]. Despite being biotin auxotrophic, genes of the incomplete biotin pathway are transcriptionally repressed by BioQ in C. glutamicum [56]. Higher RNA-levels of $t c t A B C$, which code for the citrate uptake system of C. glutamicum [57] might be due to citrate present in thick juice as citrate can be used as carbon source by C. glutamicum [58]. Cg3226 is adjacent to lldD, which is essential for lactate utilization in C. glutamicum [41] and both are regulated by LldR $[59,60]$. Cg3226 is suggested to be a lactate transporter [41] and lactate can be found in small amounts in thick juice (data not shown).

Reduced expression levels on thick juice were found for NAD synthesis genes nadACS. NAD biosynthesis involves three enzymatic reactions starting with aspartate which is converted to nicotinate mononucleotide via iminoaspartate and quinolinate usually catalyzed by Nad-ABC. In C. glutamicum the enzyme catalyzing the reaction from aspartate to iminoaspartate is unknown as there is no $\operatorname{nadB}$ [61]. From nicotinate mononucleotide NAD is build and this can be further phosphorylated by PpnK [62] to the reduced NADP. Furthermore prpCD showed lower expression which are part of propionate metabolism consisting of prpDBC in C. glutamicum and is regulated by PrpR [63]. With cg0924 and cg0926 two genes involved in iron uptake show lower expression levels, suggesting good iron conditions in thick juice. Supporting this also SufR regulated suf genes, which are important for assembly of iron-sulfur cluster, and $c y s R$, involved in regulation of sulfur metabolism [64], are found to be differentially expressed.

For the production of amino acids and diamines thick juice was superior to pure sucrose since in each case the volumetric production rate was higher (Figure 2). In the case of L-glutamate and L-lysine significantly higher concentrations accumulated with thick juice than with pure sucrose (Table 3 ). In addition, growth and sucrose utilization was faster (Figure 1). Thus, thick juice had a beneficial effect on both, product yields and the carbon source uptake rates. By contrast, production of $\mathrm{L}$-arginine and putrescine, which is derived from L-ornithine, an intermediate of L-arginine biosynthesis, was characterized by comparable final product concentrations on pure sucrose and on thick juice (Table 3). Apparently, L-arginine and putrescine product yields were limited by factors other than by compounds provided by thick juice. These factors remain unknown at least for C. glutamicum, however in higher plants like tobacco it is known that high putrescine concentrations can decrease ATP synthesis [65]. For L-arginine and putrescine production, the increased volumetric productivities as compared to pure sucrose were only due to faster growth and carbon source uptake, and thus, increased by to a lesser 
Citation: Meiswinkel TM, Lindner SN, Wendisch VF (2014) Thick Juice-Based Production of Amino Acids and Putrescine by Corynebacterium glutamicum. J Biotechnol Biomater 4: 167. doi:10.4172/2155-952X.1000167

Page 5 of 6

extent as those for L-lysine and L-glutamate (Figure 2). It is interesting to note that growth of the L-arginine and putrescine producing strains was about twofold faster with thick juice than with pure sucrose, while the growth rates of the L-glutamate producing strain only increased by about one third and that of the L-lysine producer was comparable on thick juice and on pure sucrose.

\section{Conclusion}

In this study it was shown that sugar beet thick juice is a suitable carbon source for the industrial heavily used C. glutamicum. Microarray data revealed beneficial influence of some remaining ingredients in sugar beet thick juice. Growth as well as L-glutamate, L-lysine, L-arginine and putrescine production with thick juice was accelerated and/or increased. Therefore thick juice as carbon source for amino acid or diamine production is superior sucrose.

\section{Acknowledgment}

We would like to thank Dr. Koch and Dr. Bruhns from Pfeifer and Langen $\mathrm{GmbH}$ and Co. KG for providing thick juice samples. We acknowledge support for the Article Processing Charge by the Deutsche Forschungsgemeinschaft and the Open Access Publication Fund of Bielefeld University.

\section{References}

1. Lau MW, Gunawan C, Balan V, Dale BE (2010) Comparing the fermentation performance of Escherichia coli KO11, Saccharomyces cerevisiae $424 \mathrm{~A}(\mathrm{LNH}$ ST) and Zymomonas mobilis AX101 for cellulosic ethanol production. Biotechnol Biofuels 3: 11

2. Bormann S, Baer ZC2, Sreekumar S3, Kuchenreuther JM2, Dean Toste F4, et al. (2014) Engineering Clostridium acetobutylicum for production of kerosene and diesel blendstock precursors. Metab Eng 25: 124-130.

3. Pfeifer \& Langen: Wissenswertes über Zucker. Available from World Wide Web: http://www.koelner-zucker.de/media/Wissenwertes_ueber_Zucker.pdf 2011 cited 15 May 2013. 2011.

4. Juste A, Van Trappen S, Verreth C, Cleenwerck I, De Vos P, et al. (2012) Characterization of Tetragenococcus strains from sugar thick juice reveals a novel species, Tetragenococcus osmophilus sp. nov., and divides Tetragenococcus halophilus into two subspecies, T. halophilus subsp halophilus subsp. nov. and T. halophilus subsp. flandriensis subsp. nov. Int $J$ Syst Evol Microbiol 62: 129-137.

5. Justé A, Lievens B, Frans I, Klingeberg M, Michiels CW, et al. (2008) Presen knowledge of the bacterial microflora in the extreme environment of sugar thick juice. Food Microbiol 25: 831-836.

6. Justé A, Lievens B, Klingeberg M, Michiels CW, Marsh TL, et al. (2008) Predominance of Tetragenococcus halophilus as the cause of sugar thick juice degradation. Food Microbiol 25: 413-421.

7. Justé A, Krause MS, Lievens B, Klingeberg M, Michiels KA (2008) Protective effect of hop beta-acids on microbial degradation of thick juice during storage. J Appl Microbiol 104: 51-59.

8. Atiyeh H, Duvnjak Z (2002) Production of fructose and ethanol from sugar bee molasses using Saccharomyces cerevisiae ATCC 36858. Biotechnol Prog 18 234-239.

9. Ghazi I, Fernandez-Arrojo L, Gomez De Segura A, Alcalde M, Plou FJ, et al. (2006) Beet sugar syrup and molasses as low-cost feedstock for the enzymatic production of fructo-oligosaccharides. J Agric Food Chem 54: 2964-2968.

10. Schneider J, Wendisch VF (2010) Putrescine production by engineered Corynebacterium glutamicum. Appl Microbiol Biotechnol 88: 859-868.

11. Schneider J, Eberhardt D, Wendisch VF (2012) Improving putrescine production by Corynebacterium glutamicum by fine-tuning ornithine transcarbamoylase activity using a plasmid addiction system.Appl Microbiol Biotechnol 95: 169178

12. Mimitsuka T, Sawai H, Hatsu M, Yamada K (2007) Metabolic engineering of Corynebacterium glutamicum for cadaverine fermentation. Biosci Biotechnol Biochem 71: 2130-2135.

13. Kind S, Kreye S, Wittmann C (2011) Metabolic engineering of cellular transport for overproduction of the platform chemical 1,5-diaminopentane in
Corynebacterium glutamicum. Metab Eng 13: 617-627.

14. Tateno T, Okada Y, Tsuchidate T, Tanaka T, Fukuda H, et al. (2009) Direct production of cadaverine from soluble starch using Corynebacterium glutamicum coexpressing alpha-amylase and lysine decarboxylase. Appl Microbiol Biotechnol 82: 115-121.

15. Wieschalka S, Blombach B, Eikmanns BJ (2012) Engineering Corynebacterium glutamicum for the production of pyruvate. Appl Microbiol Biotechnol 94: 449459.

16. Krause FS, Blombach B, Eikmanns BJ (2010) Metabolic engineering of Corynebacterium glutamicum for 2-ketoisovalerate production. Appl Environ Microbiol 76: 8053-8061.

17. Okino S, Noburyu R, Suda M, Jojima T, Inui M, et al. (2008) An efficient succinic acid production process in a metabolically engineered Corynebacterium glutamicum strain. Appl Microbiol Biotechnol 81: 459-464.

18. Litsanov B, Kabus A, Brocker M, Bott M (2012) Efficient aerobic succinate production from glucose in minimal medium with Corynebacterium glutamicum. Microbial biotechnology 5: 116-128.

19. Litsanov B, Brocker M, Bott M (2012) Glycerol as a substrate for aerobic succinate production in minimal medium with Corynebacterium glutamicum. Microbial biotechnology 6: 189-195.

20. Litsanov B, Brocker M, Bott M (2012) Toward homosuccinate fermentation: metabolic engineering of Corynebacterium glutamicum for anaerobic production of succinate from glucose and formate. Appl Environ Microbiol 78: 3325-3337.

21. Inui M, Kawaguchi $H$, Murakami S, Vertès AA, Yukawa $H$ (2004) Metabolic engineering of Corynebacterium glutamicum for fuel ethanol production under oxygen-deprivation conditions. J Mol Microbiol Biotechnol 8: 243-254.

22. Blombach B, Riester T, Wieschalka S, Ziert C, Youn JW, et al. (2011) Corynebacterium glutamicum tailored for efficient isobutanol production. App Environ Microbiol 77: 3300-3310.

23. Schneider J, Niermann K, Wendisch VF (2011) Production of the amino acids l-glutamate, l-lysine, l-ornithine and l-arginine from arabinose by recombinant Corynebacterium glutamicum. J Biotechnol 154: 191-198.

24. Jensen JV, Wendisch VF (2013) Ornithine cyclodeaminase-based proline production by Corynebacterium glutamicum. Microb Cell Fact 12: 63.

25. Heider SA, Peters-Wendisch P, Wendisch VF (2012) Carotenoid biosynthesis and overproduction in Corynebacterium glutamicum. BMC Microbiol 12: 198

26. Takahashi C, Shirakawa J, Tsuchidate T, Okai N, Hatada K, et al. (2012) Robust production of gamma-amino butyric acid using recombinant Corynebacterium glutamicum expressing glutamate decarboxylase from Escherichia coli.Enzyme Microb Technol 51: 171-176.

27. Moon MW, Kim HJ, Oh TK, Shin CS, Lee JS, et al. (2005) Analyses of enzyme II gene mutants for sugar transport and heterologous expression of fructokinase gene in Corynebacterium glutamicum ATCC 13032. FEMS Microbiol Lett 244 259-266.

28. Lindner SN, Seibold GM, Henrich A, Krämer R, Wendisch VF (2011) Phosphotransferase system-independent glucose utilization in corynebacterium glutamicum by inositol permeases and glucokinases. Appl Environ Microbiol 77: 3571-3581.

29. Ikeda M, Mizuno Y, Awane S, Hayashi M, Mitsuhashi S, et al. (2011) Identification and application of a different glucose uptake system that functions as an alternative to the phosphotransferase system in Corynebacterium glutamicum. Appl Microbiol Biotechnol 90: 1443-1451.

30. Gopinath V, Meiswinkel TM, Wendisch VF, Nampoothiri KM (2011) Amino acid production from rice straw and wheat bran hydrolysates by recombinant pentose-utilizing Corynebacterium glutamicum. Appl Microbiol Biotechnol 92: 985-996.

31. Kawaguchi H, Vertès AA, Okino S, Inui M, Yukawa H (2006) Engineering of a xylose metabolic pathway in Corynebacterium glutamicum. Appl Environ Microbiol 72: 3418-3428.

32. Kawaguchi H, Sasaki M, Vertès AA, Inui M, Yukawa H (2008) Engineering of an L-arabinose metabolic pathway in Corynebacterium glutamicum. Appl Microbio Biotechnol 77: 1053-1062.

33. Meiswinkel TM, Gopinath V, Lindner SN, Nampoothiri KM, Wendisch VF (2013) Accelerated pentose utilization by Corynebacterium glutamicum fo 
Citation: Meiswinkel TM, Lindner SN, Wendisch VF (2014) Thick Juice-Based Production of Amino Acids and Putrescine by Corynebacterium glutamicum. J Biotechnol Biomater 4: 167. doi:10.4172/2155-952X.1000167

accelerated production of lysine, glutamate, ornithine and putrescine.Microbial biotechnology 6: 131-140.

34. Seibold G, Auchter M, Berens S, Kalinowski J, Eikmanns BJ (2006) Utilization of soluble starch by a recombinant Corynebacterium glutamicum strain: growth and lysine production. J Biotechnol 124: 381-391.

35. Tateno T, Fukuda H, Kondo A (2007) Production of L-Lysine from starch by Corynebacterium glutamicum displaying alpha-amylase on its cell surface. Appl Microbiol Biotechnol 74: 1213-1220.

36. Kotrba $\mathrm{P}$, Inui M, Yukawa $\mathrm{H}$ (2003) A single V317A or V317M substitution in Enzyme II of a newly identified beta-glucoside phosphotransferase and utilization system of Corynebacterium glutamicum $\mathrm{R}$ extends its specificity towards cellobiose. Microbiology 149: 1569-1580.

37. Brabetz W, Liebl W, Schleifer KH (1991) Studies on the utilization of lactose by Corynebacterium glutamicum, bearing the lactose operon of Escherichia coli. Arch Microbiol 155: 607-612.

38. Barrett E, Stanton C, Zelder O, Fitzgerald G, Ross RP (2004) Heterologous expression of lactose- and galactose-utilizing pathways from lactic acid bacteria in Corynebacterium glutamicum for production of lysine in whey. Appl Environ Microbiol 70: 2861-2866.

39. Uhde A, Youn JW, Maeda T, Clermont L, Matano C, et al. (2012) Glucosamine as carbon source for amino acid-producing Corynebacterium glutamicum.App Microbiol Biotechnol 97: 1679-1687.

40. Eggeling L, Bott M (2005) Handbook of Corynebacterium glutamicum. CRC Press LLC, Boca Raton, FL.

41. Stansen C, Uy D, Delaunay S, Eggeling L, Goergen JL, et al. (2005) Characterization of a Corynebacterium glutamicum lactate utilization operon induced during temperature-triggered glutamate production.Appl Environ Microbiol 71: 5920-5928.

42. Wendisch VF, de Graaf AA, Sahm H, Eikmanns BJ (2000) Quantitative determination of metabolic fluxes during coutilization of two carbon sources: comparative analyses with Corynebacterium glutamicum during growth on acetate and/or glucose. J Bacteriol 182: 3088-3096.

43. Kinoshita S, Udaka S, Shimono M (2004) Studies on the amino acid fermentation. Part 1. Production of L-glutamic acid by various microorganisms. J Gen Appl Microbiol 50: 331-343.

44. Georgi T, Rittmann D, Wendisch VF (2005) Lysine and glutamate production by Corynebacterium glutamicum on glucose, fructose and sucrose: roles of malic enzyme and fructose-1,6-bisphosphatase. Metab Eng 7: 291-301.

45. Rittmann D, Lindner SN, Wendisch VF (2008) Engineering of a glycerol utilization pathway for amino acid production by Corynebacterium glutamicum. Appl Environ Microbiol 74: 6216-6222.

46. Ishige T, Krause M, Bott M, Wendisch VF, Sahm H (2003) The phosphate starvation stimulon of Corynebacterium glutamicum determined by DNA microarray analyses. J Bacteriol 185: 4519-4529.

47. Lange C, Rittmann D, Wendisch VF, Bott M, Sahm H (2003) Global expression profiling and physiological characterization of Corynebacterium glutamicum grown in the presence of L-valine. Appl Environ Microbiol 69: 2521-2532.

48. Wendisch VF (2003) Genome-wide expression analysis in Corynebacterium glutamicum using DNA microarrays. J Biotechnol 104: 273-285.

49. Abe S, Takayarna K, Kinoshita S (1967) Taxonomical studies on glutamic acid producing bacteria. J Gen Appl Microbiol 13: 279-301.

50. Radmacher E, Stansen KC, Besra GS, Alderwick LJ, Maughan WN, et al (2005) Ethambutol, a cell wall inhibitor of Mycobacterium tuberculosis, elicits L-glutamate efflux of Corynebacterium glutamicum. Microbiology 151: 1359-1368.

51. Meiswinkel TM, Rittmann D, Lindner SN, Wendisch VF (2013) Crude glycerol-based production of amino acids and putrescine by Corynebacterium glutamicum. Bioresour Technol 145: 254-258.

Citation: Meiswinkel TM, Lindner SN, Wendisch VF (2014) Thick Juice-Based Production of Amino Acids and Putrescine by Corynebacterium glutamicum. J Biotechnol Biomater 4: 167. doi:10.4172/2155-952X.1000167
52. Schneider J, Peters-Wendisch P Stansen KC Götker S, Maximow S, et al. (2012) Characterization of the biotin uptake system encoded by the biotininducible bioYMN operon of Corynebacterium glutamicum. BMC Microbiol 12: 6 .

53. Peters-Wendisch P, Stansen KC, Götker S, Wendisch VF (2012) Biotin protein ligase from Corynebacterium glutamicum: role for growth and L: -lysine production. Appl Microbiol Biotechnol 93: 2493-2502.

54. Jäger W, Peters-Wendisch PG, Kalinowski J, PühlerA(1996)ACorynebacterium glutamicum gene encoding a two-domain protein similar to biotin carboxylases and biotin-carboxyl-carrier proteins. Arch Microbiol 166: 76-82.

55. Peters-Wendisch PG, Schiel B, Wendisch VF, Katsoulidis E, Möckel B, et al. (2001) Pyruvate carboxylase is a major bottleneck for glutamate and lysine production by Corynebacterium glutamicum. J Mol Microbiol Biotechnol 3: 295300 .

56. Brune I, Götker S, Schneider J, Rodionov DA, Tauch A (2012) Negative transcriptional control of biotin metabolism genes by the TetR-type regulator BioQ in biotin-auxotrophic Corynebacterium glutamicum ATCC 13032 . J Biotechnol 159: 225-234

57. Brocker M, Schaffer S, Mack C, Bott M (2009) Citrate utilization by Corynebacterium glutamicum is controlled by the CitAB two-component system through positive regulation of the citrate transport genes citH and tctCBA. J Bacteriol 191: 3869-3880.

58. Polen T, Schluesener D, Poetsch A, Bott M, Wendisch VF (2007) Characterization of citrate utilization in Corynebacterium glutamicum by transcriptome and proteome analysis. FEMS Microbiol Lett 273: 109-119.

59. Gao YG, Suzuki H, Itou H, Zhou Y, Tanaka Y, et al. (2008) Structural and functional characterization of the LIdR from Corynebacterium glutamicum: a transcriptional repressor involved in L-lactate and sugar utilization. Nucleic Acids Res 36: 7110-7123.

60. Brutinel ED, Gralnick JA (2012) Preferential utilization of D-lactate by Shewanella oneidensis. Appl Environ Microbiol 78: 8474-8476.

61. Teramoto H, Suda M, Inui M, Yukawa H (2010) Regulation of the expression of genes involved in NAD de novo biosynthesis in Corynebacterium glutamicum. Appl Environ Microbiol 76: 5488-5495.

62. Lindner $\mathrm{SN}$, Niederholtmeyer $\mathrm{H}$, Schmitz $\mathrm{K}$, Schoberth SM, Wendisch VF (2010) Polyphosphate/ATP-dependent NAD kinase of Corynebacterium glutamicum: biochemical properties and impact of ppnK overexpression on lysine production. Appl Microbiol Biotechnol 87: 583-593.

63. Claes WA, Pühler A, Kalinowski J (2002) Identification of two prpDBC gene clusters in Corynebacterium glutamicum and their involvement in propionate degradation via the 2-methylcitrate cycle. J Bacteriol 184: 2728-2739.

64. Rückert C, Milse J, Albersmeier A, Koch DJ, Pühler A, et al. (2008) The dua transcriptional regulator CysR in Corynebacterium glutamicum ATCC 13032 controls a subset of genes of the McbR regulon in response to the availability of sulphide acceptor molecules. BMC Genomics 9: 483.

65. Ioannidis NE, Sfichi L, Kotzabasis K (2006) Putrescine stimulates chemiosmotic ATP synthesis. Biochim Biophys Acta 1757: 821-828.

Submit your next manuscript and get advantages of OMICS Group submissions

Unique features:

User friendly/feasible website-translation of your paper to 50 world's leading languages Audio Version of published paper Digital articles to share and explore

Special features:

300 Open Access Journals

25,000 editorial team

21 days rapid review process

Quality and quick editorial, review and publication processing

Indexing at PubMed (partial), Scopus, EBSCO, Index Copernicus and Google Scholar etc

Sharing Option: Social Networking Enabled

Authors, Reviewers and Editors rewarded with online Scientific Credits

Befter discount for your subsequent articles

Submit your manuscript at: http://www.omicsonline.org/submission 